\title{
Using Culture Walks To Enhance Hispanic Culture In The Second Language Classroom
}

Deborah J. Gill (Email: djg25@psu.edu), Pennsylvania State University, DuBois

\begin{abstract}
The present paper discusses both the methodologies on and student reaction to teaching Hispanic Culture through the use of authentic culture walks created by the instructor as well as students. Through the use of a virtual learning community, students learn Hispanic culture through reading discussions, viewing authentic video, reading descriptions, and through collaboration with others (from other countries and throughout the United States) by both synchronous and asynchronous means.
\end{abstract}

\section{INTRODUCTION}

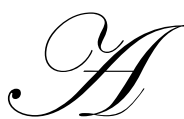

$\mathrm{n}$ intricate part of any society is its culture. Therefore, when teaching Hispanic civilization and culture and Spanish language courses, society and culture is the principal foundation and cornerstone. The purpose of this study is to introduce virtual culture walks, including: what they are; how they are used; how faculty and students can participate in them; and becoming involved in the Culture Walk Project

Foreign language learning is comprised of a number of components and competencies. These include grammatical competence, communicative competence, language proficiency, and cultural competence. All of the previous competencies are intertwined, each building and growing on one another. The focus of this paper is culture and therefore teaching culture and cultural competence in civilization and culture courses as well as foreign language courses.

Foreign language learning itself implicitly infers that it is also foreign culture learning. But, what is "culture"? According to Kramsch (1993),

Culture in language learning is not an expendable fifth skill, tacked on, so to speak, to the teaching of speaking, listening, reading, and writing. It is always in the background, right from day one, ready to unsettle the good language learners when they expect it least, making evident the limitations of their hard-won communicative competence, challenging their ability to make sense of the world around them. (1993:1)

Along the same lines, Duranti (1997) states that,

to be part of a culture means to share the propositional knowledge and the rules of inference necessary to understand whether certain propositions are true (given certain premises). To the propositional knowledge, one might add the procedural knowledge to carry out tasks such as cooking, weaving, farming, fishing, giving a formal speech, answering the phone, asking for a favor, writing a letter for a job application (1997:28-29).

\section{Purpose and Description of the Project}

This project grew out of a number of important factors, including the lack of Hispanic language in the community and surrounding communities, the non-existence of Hispanic television and radio station broadcasts available to the community, and, most importantly, the need for more authentic language and cultural materials and input. The National Standards for Foreign Language Learning are divided into five areas: Communities, Communication, Comparisons, Cultures, and Connections. These areas are inter-related and inter-connected as shown in Figure 1 below: 
Figure 1: The Five "Cs" of Foreign Language Study

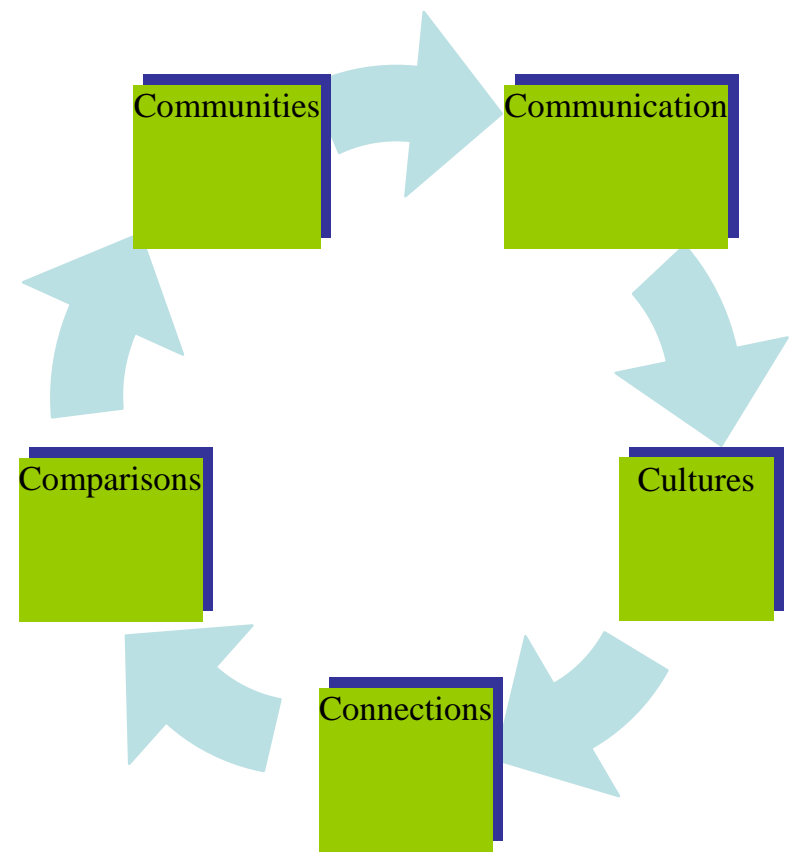

In order to meet as many of these standards as possible, World of Diversity, a Virtual Learning Environment, was created. The Culture Walks which have been developed provide an opportunity to satisfy each of the five Cs of the National Standards.

Before beginning this discussion, it is necessary to give a brief background about World of Diversity, the Virtual Learning Environment in which the Culture Walks are located.

World of Diversity (http://diversity.ds.psu.edu:7000 and shown as Figure 2 below) is a web-based virtual learning environment using enCore Xpress. World of Diversity was developed in 2001 as a virtual community created to promote diversity, collaboration, and interdisciplinary studies. Unlike text-based synchronous virtual communities, World of Diversity incorporates not only text, but rather images, sound, and video. World of Diversity is currently divided into a number of different sectors with the focal point at "World of Diversity", the home of all new characters as well as any guest log-ins. When one connects, they are greeted with a Welcome Message and "It's a Small World" playing in the background, promoting the idea of everyone working together, collaborating with one another, and learning about other cultures and customs. Currently there are six main sectors: (1) World of Friends, (2) Programmer's Alley, (3) Women's Studies, (4) Kid's Zone, (5) World of Languages, and (6) World Cultures. For the present paper we will be concerned only with World of Diversity for the acquisition of cultural competence, and therefore the sectors "World of Languages" and "World Cultures" will be our focus.

Figure 2: World of Diversity 


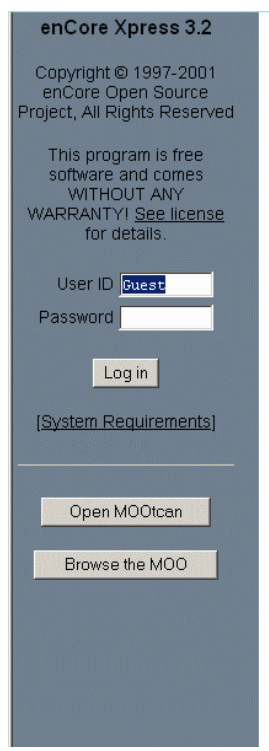

Welcome to World of Diversity!

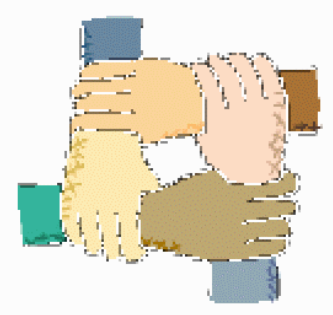

World of Diversity is a virtual community created by The Pennsylvania State University--DuBois, dedicated to promoting diversity.

If you have questions or are interested in becoming part of World of Diversity, please send an email to World of Diversity at psu_diversity@yahoo.com. If you are requesting a character, the following information is required:

Real Name;

Name of Character requesting:

Valid academic email address (if you do not have one, or if you are not within the field of academics, please

explain);

School or University; and

5. Reason for wanting a character

We will answer your message within a couple of days of receipt.

The remainder of this paper will discuss (1) what a Culture Walk is, (2) National Standards and activities which can be accomplished using Culture Walks, (3) how students can participate in Culture Walks, and (4) how one can become involved in the Culture Walk Project.

\section{WHAT ARE CULTURE WALKS?}

One of the principal missions of World of Diversity is to promote cultural diversity and interdisciplinary studies at all grade levels, from Pre-K through University-level classes. Therefore, the Culture Walks which are created are generally created in two languages-English (found in the "World Cultures" region) and the native language of the country in which the Culture Walk takes place (found in the "World Languages" region), i.e., for our purposes here, Spanish. In this section, we will discuss Culture Walks within two frameworks: (1) in the realm of Hispanic Civilization and Culture studies taught in English and (2) within the scaffold of foreign language learners and classes taught in the target language. But first, what exactly is a Culture Walk?

Culture Walks are virtual walking tours of countries and cities throughout the world. When taking a Culture Walk, a person will enter into the first location and read a description of what will be encountered on the "tour". The description is written in a manner that will tempt the reader to continue on the "tour" in order to explore and virtually "live" the moment in that particular city, as we will see when we explore Old Madrid, Spain below.

\section{Culture Walks and Hispanic Civilization and Culture Courses}

As stated previously, World of Diversity is divided into numerous regions and sub-regions. One of those regions is "World Cultures". This region is broken into sub-regions such as "Hispanic Cultures", "French Cultures", etc. And, within each sub-region, there are other subregions. Since we are concerned with Hispanic Culture Walks, Figure 3 below shows the division of the sub-region of "Hispanic Cultures".

Figure 3: Hispanic Cultures Region 


\section{Hispanic Cultures \\ $\hat{\theta}(0)$}

Have you ever wanted to explore the Hispanic World and just have not had the time? Would you like to be able to see Spain and the Guggenheim Museum, or the Gaudi's famous Sagrada Familia church? How about experience the Tango in Argentina?

Would you like to explore the flora and the fauna of Costa Rica or visit with the Sea Turtles in the Galapagos Islands?

Well, you have your chance now! Please feel free to explore the different lands here! You can read vivid descriptions of areas and see photos brilliant photos! Look at the objects that you find in each room or interact with the objects to find out more information!

But, best of all, HAVE FUN!!!
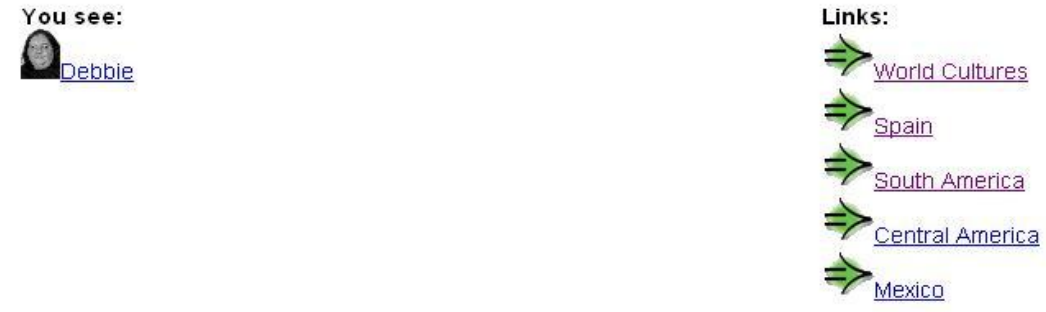

Figure 3 shows that a person may visit Spain, South America, Central America, or Mexico. Within each one of these "sub-regions" are links which will lead to a specific Culture Walk. As an example, let's explore Old Madrid, Spain.

Figure 4 is the starting point for a walking tour through a region of Spain, Old Madrid. As can be seen, there is a brief historical description, an authentic picture (all photos are authentic, i.e., either taken by the author of this paper or donated by those involved in a project entitled "Web Portal of Copyright Free Materials for Foreign Language Educators") from a trip taken to this part of Spain, and then an explanation of what is included in the "tour". The "Links" will be used to leisurely walk through Old Spain. By clicking on the "Puerta del Sol" link, you will arrive in the Puerta del Sol, as seen in Figure 5 below:

The person taking the Old Madrid Culture Walk has now arrived in the Puerta del Sol. This location is typical of one of the locations found in a Culture Walk. On the left you see "You see:" while on the right you see "Links:". The "Links" will allow you to continue on the Culture Walk, eventually ending back at the introductory room and the link to the "Walk through Spain (English)" link, which leads to the Hispanic Cultures page.

Leisurely strolling through the Culture Walk by reading the descriptions and looking at the picture on the page provides a pleasant overall description of the tour. However, to get the true essence of each of the locations (for example, the "Puerta del Sol"), it is necessary to explore a bit more. When one travels, it is seldom that that person would just walk and not "look" at the sites surrounding him/her. The Culture Walks also provide the opportunity to "look" at, examine, and sometimes even interact with the surroundings. This is done through the "You see:" links, which do not move the visitor to another location but rather provides specific information about that particular object in that particular location. In Figure 5 above, beneath "You see:" are three links: (1) The Bear and the Strawberry Tree, (2) The Post Office, and (3) Statue of Carlos III. By clicking on one or all of these links, an explanation of what each one is given. Figure 6 below is what one would see if he/she clicked on the link to "The Bear and the Strawberry Tree":

Figure 4: Beginning of Culture Walk of Old Madrid, Spain 


\section{Old Madrid \#1}

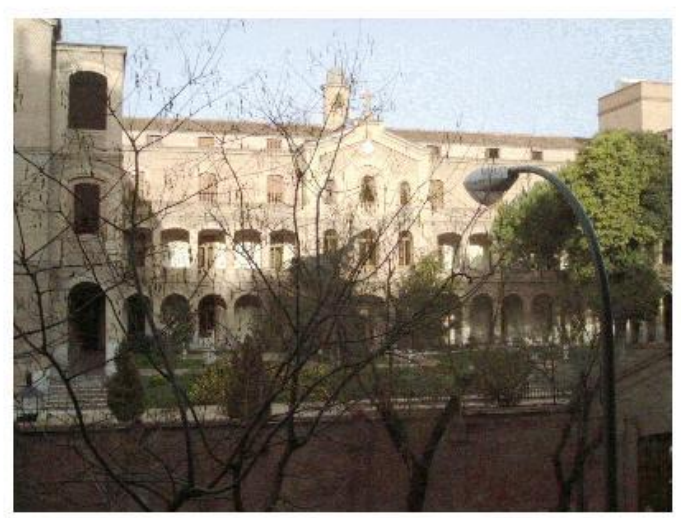

$\mathrm{Hi}$ and Welcome to Madrid. My name is Greg and I'll be your tour guide. Today we're going to explore a part of the city known as Old Madrid. In 1561 King Phillip II chose Madrid as the capital of Spain. Since then, Madrid has grown to become synonomous with the art, the people, the food, and the flair that Spain is known for. Today our tour today will include the Puerta del Sol, the Plaza Mayor, the Plaza de Oriente, and the Campo del Moro. At each of the sites we'll find places of interest that will improve our understanding of the culture.

You see:

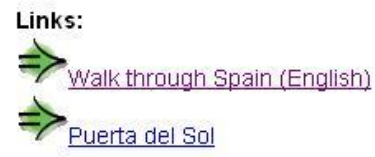

Figure 5: Puerta del Sol, Madrid, Spain

\section{Puerta del Sol}

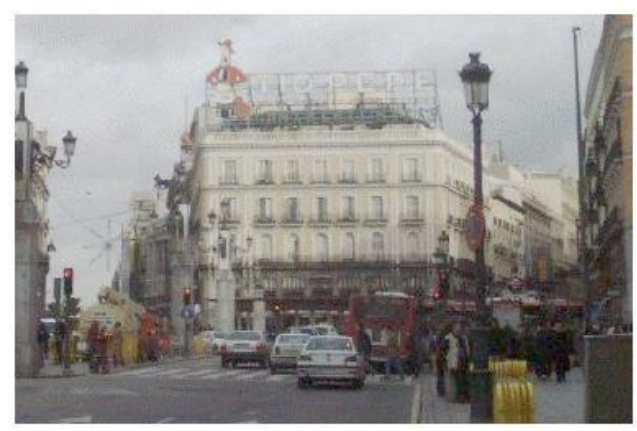

Our first stop is Puerta del Sol. As so many main streets empty here, it's no wonder why Puerta del Sol has become a hub of activity. Originally, this site marked the eastern entrance into the city. Despite its name, Puerta del Sol has a distinct crescent moon shape. With the additions of several important buildings such as the casa de Correos (Post Office), Puerta del Sol not only became a center of "cafe society," but also a focal point of political milestones and events: in 1912, Jose Canalejas, the president of the government, was assasinated; in 1931 they proclaimed the Second Republic from the balcony of the Ministry of the Interior. Today, with its many shops and cafes, Puerta del Sol remains one of the most popular locations in Old Madrid. Before leaving. be sure to investigate some of the attractions located here.
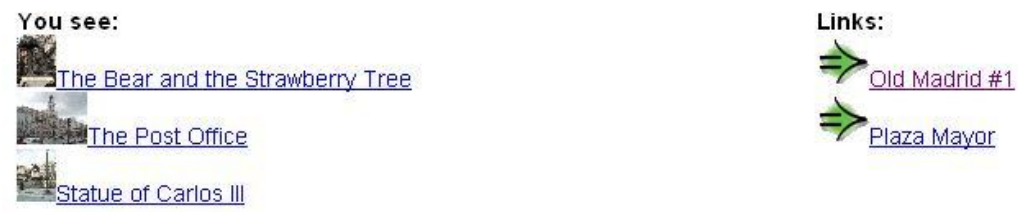
Figure 6 not only gives a brief historical description of the symbolism behind this particular item which is found in the Puerta del Sol, but also the subtle cultural information about the "strawberry tree". This is information which those who are not from Spain might not know and might wonder about since strawberries don't grow on trees!

\section{Figure 6: The Bear and the Strawberry Tree, Puerta del Sol, Madrid, Spain}

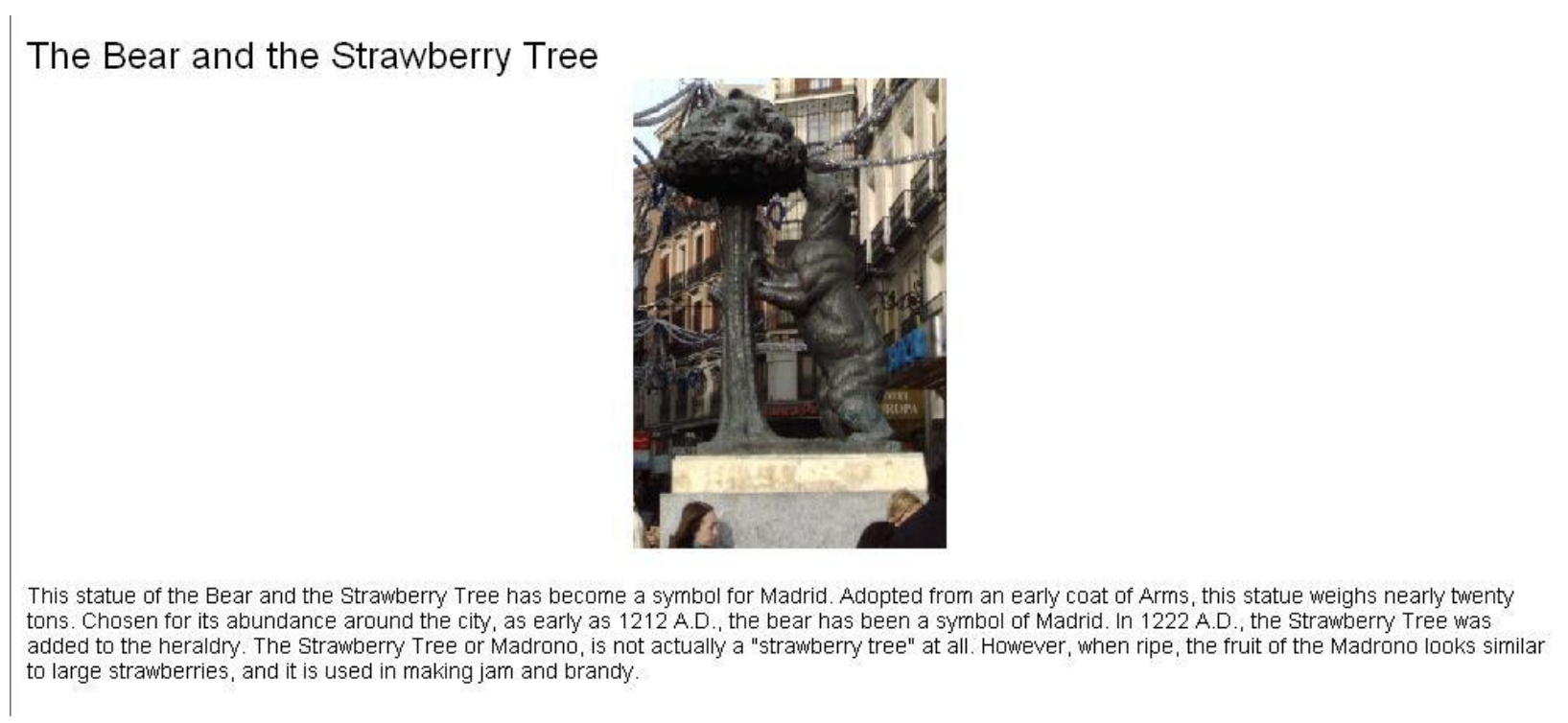

\section{Culture Walks and Second Language Courses}

We have just observed what a typical Culture Walk would consist of when used in non-target language situations. Culture Walks may also be used in the second language classroom (in this case, Spanish), in the target language.

As explained previously, most of the Culture Walks are created so that they are available in two languages, English and the target language. Therefore, teachers who would like to use Culture Walks in the target language have the same opportunities as those who would like to use them in English. An example once again is Old Madrid (Madrid Antigua) as seen in Figure 7 below:

As is seen, Figure 7 below is parallel to Figure 4 shown earlier in this paper, with the only difference being that everything is in Spanish, the target language. The language which is used is basic in order to allow young children who are just learning Spanish and second language learners at all levels to be able to follow and understand the language, while at the same time picking up new vocabulary and idiomatic expressions (not seen on this page).

An added component in the target language is interactive objects. An "interactive object" is an object that would be found under the "You see:" link and will appear exactly as any other object there. The difference, however, is that when one reads the description, there is the possibility to "interact" with the object. We will demonstrate two of these objects here.

The first object is a "Plato de Tapas" which might be found in a restaurant where someone has ordered "tapas" and something to drink. Figure 8 below is an example of an interactive object known as "Plato de tapas": 
Figure 7: Culture Walk of Old Madrid, Spain in Spanish

\section{Madrid Antigua \#1}

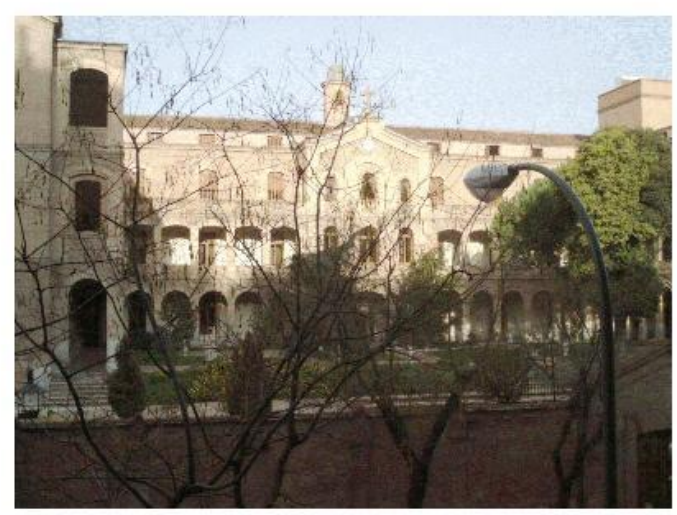

!>Hola! !>Bienvenido/a a Madrid! Soy Gregorio y sere' su gui'a del viaje. Hoy vamos a explorar la parte de Madrid que se Ilama "Madrid vieja". En 1561, el rey Felipe II nombro' Madrid la capital de Espan a. Desde ahora, Madrid ha crecido y esta' reconocido por el arte, la gente, la comida, y su esencia.

Hoy vamos a explorar algunos sitios importantes. Estos incluyen: La Puerta del Sol, la Plaza Mayor, la Plaza del Oriente, y el Campo del Moro. En cada lugar, encontraremos sitios de intere's que nos ayudara'n a entender la cultura espan ola mejor. ! > Vamos!

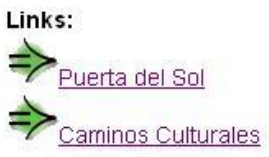

Figure 8: Plato de tapas

Plato de tapas

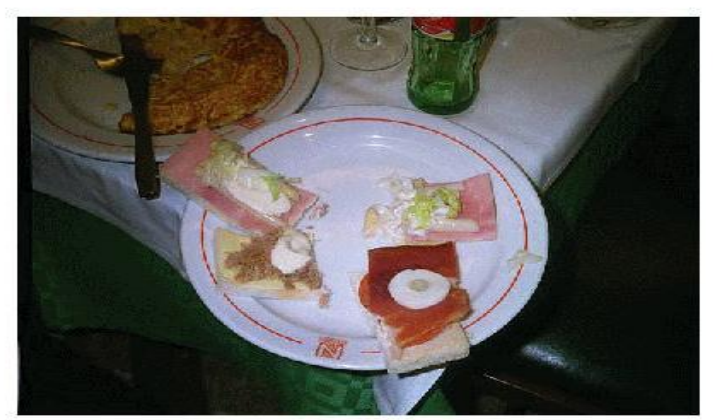

?>Tienes hambre? Aqui' hay un plato de tapas deliciosas. ?>Por que' no comas algunas tapas? Si no hay ninguna tapa, haz algunas ;)

Figure 8 provides an image so that students will have a general idea of what a "tapa" is, even if they have never heard the word before. By reading the description, there is a hint that one might be able to do something with this object, i.e., "eat" or "make" tapas. Therefore, if person should type "Come tapas" ("Eat tapas") or "Hace tapas" ("Make tapas"), the following would happen: 


\section{Figure 9: Interaction with Plato de Tapas Interactive Object}

come tapas

Debbie esta' comiendo empanadillas.

come tapas

Debbie esta' comiendo patatas con alioli.

come tapas

Debbie esta' comiendo calamares.

come tapas

Debbie esta' comiendo pulpo con vinagre.

come tapas

Debbie va a coger una tapa pero no hay mas!

hace tapas

Debbie ha preparado unas tapas ma's!

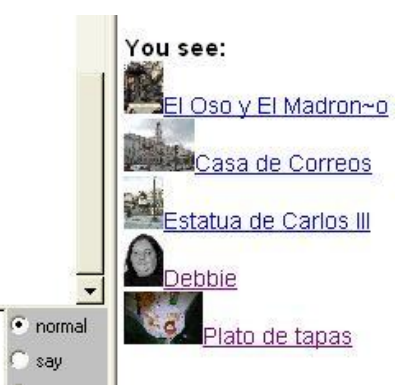

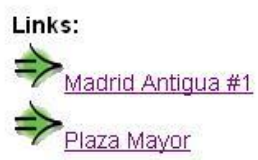

After reading the description of the object "Plato de Tapas", "Debbie" has given the command "come tapas", as can be seen on the left hand side of Figure 9. The first response to the command is "Debbie está comiendo empanadillas" ("Debbie is eating empanadillas"). "Debbie" appears to be very hungry so she gives the command a number of times, getting a different "tapa" each time, until suddenly there are not any more tapas left! ("Debbie va a coger una tapa pero ny hay más!"). So, she "makes" some more ("hace tapas") and receives the message "Debbie ha preparado unas tapas más" ("Debbie has prepared more tapas").

A second interactive object is called "El Buho"1 (the "Owl"), as seen in Figure 10 below:

\section{Figure10: Interactive Object "El Buho"}

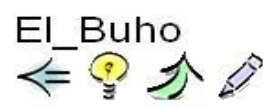

Es un sabio buho blanco con los ojos morenos y profundos. Sabe hablar espan ol. Si quieres oir sus consejos, teclea escucha buho.

\section{Figure 11: Responses by El Buho}

El Buho is an interactive object in which visitors may talk to in order to hear advice by typing "escucha buho". Figure 11 demonstrates the types of responses given by El Buho:

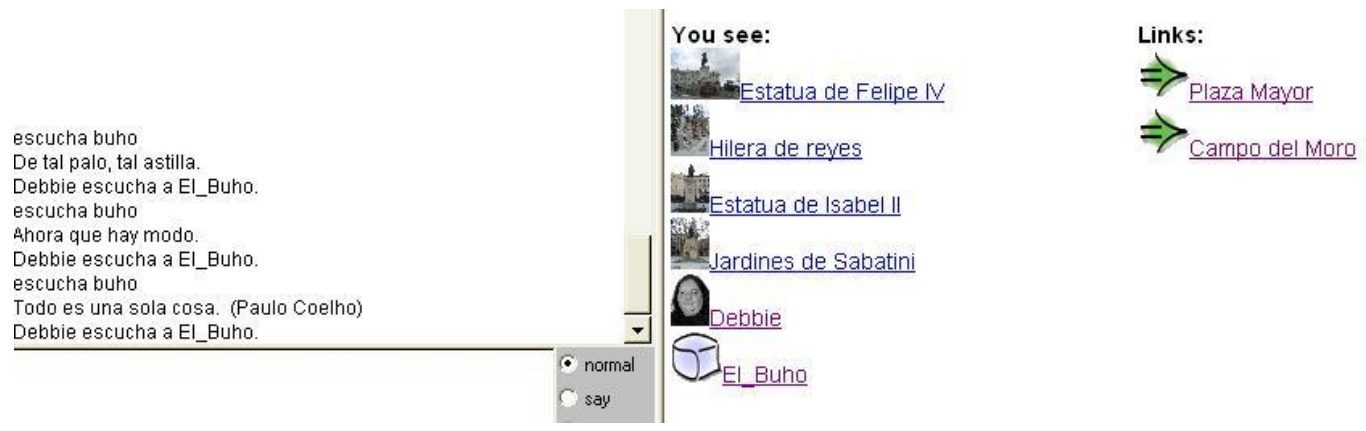

\footnotetext{
1 "El Buho" is one of a number of objects that has been created by Jeffery Forney, a Spanish teacher at Oakcrest High School, New Jersey.
} 
When asked for advice, El Buho provides visitors with idiomatic expressions, some serious others less serious. This interactive object has been programmed with many sayings, with the possibility of adding and/or changing them as needed.

In this section we have seen what is involved in a Culture Walk, both in English and in the target language Spanish. In the next section we will discuss why Culture Walks are an important component to cultural competence and meeting National Foreign Language Standards. Appendix A also provides a number of specific activities using Culture Walks which can be completed to meet Local, State, and National Foreign Language Program Standards.

\section{Why Culture Walks?}

Each Culture Walk is created through the use of authentic images, room descriptions written by those knowledgeable about the specific location, and objects (static and interactive) which are representative of real sites and symbols in each of those locations.

National Foreign Language Standards are incorporated into each and every state standards and benchmarks for foreign language development. We must provide an opportunity for students to develop each of these areas through:

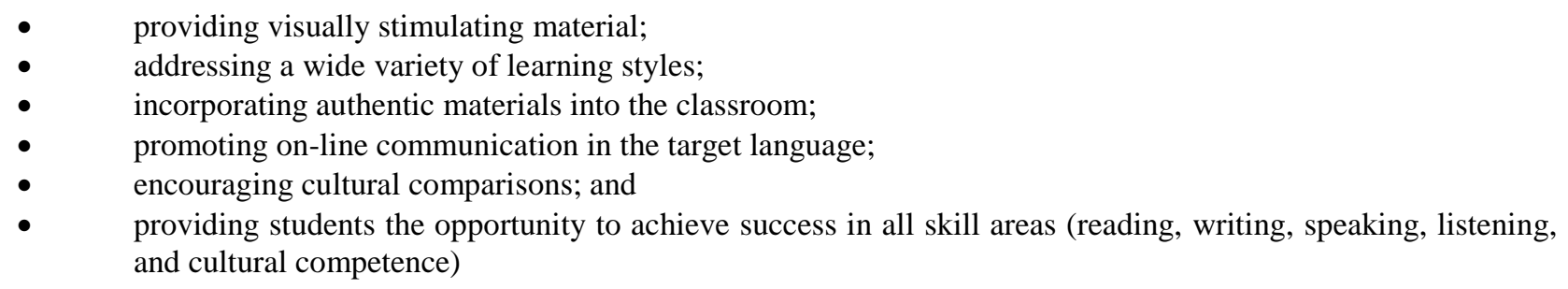

Using the National Standards for Foreign Language Education (Figure 1 above), we will discuss activities which can be accomplished through the use of Culture Walks.

\section{Standard \#1: Communication (Communicate in Languages Other Than English)}

The first standard is "Communication" which is divided into three subparts: " (1.1) Students engage in conversations, provide and obtain information, express feelings and emotions, and exchange opinions; (1.2) Students understand and interpret written and spoken language on a variety of topics; and (1.3) Students present information, concepts and ideas to an audience of listeners or readers on a variety of topics." (National Standards 2004)

When using Culture Walks which are created in the target language, students routinely meet 1.2 of this standard through the reading of the room (site) descriptions, and looking at and interacting with the objects which are found in each location. Through the use of this information, Standards 1.1 and 1.3 may also be met through activities that extend from the Culture Walk itself. Examples of these types of activities can be found in the attached Appendix A.

\section{Standard \#2: Cultures (Gain Knowledge and Understanding of Other Cultures)}

The second standard is "Cultures" which is divided into two subparts: "(2.1) Students demonstrate an understanding of the relationship between the practices and perspectives of the culture studied; and (2.2) Students demonstrate an understanding of the relationship between the products and perspectives of the culture studied." (National Standards 2004).

In order to meet the two subparts of this standard, students must be able to interact with the culture. This may be done through the use of the interactive objects found in each location. For example, in order to meet 2.1, students might interact with a robot who is the President of a country or another robot who might be a child who lives 
in a house. The "social discourse" with these two robots will be different: one would expect that formal discourse will be used with the President, while informal discourse will be used with the child. In other words, students will know "what to do when and where" (National Standards 2.12004 ). On the other hand, in order to meet 2.2, students might read about a tradition and then be able to discuss the significance and value that that tradition has in that society. An example is Figure 12 below:

Figure 12: Static Object called "Tradición"

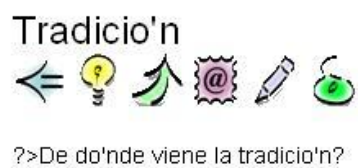

\footnotetext{
Los testimonios de las antiguas culturas mesoamericanas revelan que los nativos consideraban a la muerte como la promesa de una nueva vida anegada en esperanza. Coatlique, por ejemplo, mostraba una ma'scara de muerte, y era diosa de la tierra y de la vida; Tezcatlipoca, en cambio, era el dios de la fatalidad, y castigaba el pecado y la maldad. La primera era adorada porque prometi'a vida despue's de la muerte; el segundo era temido porque procuraba angustia a los hombres.

La llegada de los espan oles trajo consigo nuevas creencias con respecto a la vida y la muerte. La muerte produci'a terror, pues en el juicio final los justos tendri'an su recompensa y los pecadores su castigo... Y, al fin y al cabo, quie'n no podi'a contarse como pecador?

Fueron ellos quienes inculcaron la cultura de la calavera como si'mbolo de muerte y el concepto del infierno donde los re'probos habi'an de pagar sus culpas.

Sea de cualquier manera y sea vista al modo de los nativos de mesoame'rica o de la cultura espan ola, la muerte es realidad y misterio en que acaba la vida terrena. Si hay algo en el ma's alla', so'lo quienes cruzan el umbral lo han de saber

?>Acaso vale la pena saberlo ahora, cuando podemos honrar a nuestros muertos y rei'rnos a carcajadas de la huesuda calaca, mientras ma's lejos la creemos de nosotros?
}

Figure 12 represents an object that is found in one of the Culture Walks in Mexico. This object explains the concept of "Death" and one of the legends related to it. Through reading this static object and students are demonstrating an understanding of the underlying beliefs of that culture.

\section{Standard \#3: Connections (Connect with Other Disciplines and Acquire Information)}

The third standard is "Connections" is also divided into two subparts: "(3.1) Students reinforce and further their knowledge of other disciplines through the foreign language; and (3.2) Students acquire information and recognize the distinctive viewpoints that are only available through the foreign language and its cultures." (National Standards 2004).

Culture Walks provide an opportunity to meet this Standard and its subparts, first through strolling through the tour of specific cities and interacting with the objects and second through using the information that they have acquired through these strolls to "analyze the content, compare it to information available in their own language, and assess the linguistic and culture differences" (National Standards 3.2 2004). Examples of such activities can be found in Appendix A at the end of this paper.

\section{Standard \#4: Comparisons (Develop Insight into the Nature of Language and Culture)}

The next standard is "Comparisons" and there are two subparts to this standard: "(4.1) Students demonstrate understanding of the nature of language through comparisons of the language studied and their own; and (4.2) Students demonstrate understanding of the concept of culture through comparisons of the cultures studied and their own." (National Standards 2004).

Although this standard focuses more on the linguistic aspect of learning a foreign language, Culture Walks can also aid in this learning. We have already discussed the idea of interactive objects which are found in different 
locations, including El Buho ("the Owl") who provides advice through idiomatic expressions. Of course these interactive objects provide linguistic information to be able to compare and contast with English, i.e., what would a similar idiomatic expression be in English that would be parallel to the expression found in Spanish. But, in addition to this type of comparison, other interactive objects as well as the Culture Walks themselves can be used to show linguistic differences. Appendix A below provides examples of a number of these activities.

\section{Standard \#5: Communities (Participate in Multilingual Communities at Home \& Around the World)}

The final standard is that of "Communities" which is also broken into two subparts: "(5.1) Students use the language both within and beyond the school setting; and (5.2) Students show evidence of becoming life-long learners by using the language for personal enjoyment and enrichment." (National Standards 2004).

This particular standard is exactly on point with Culture Walks. First, when meeting 5.1, students stroll through the different communities of the Culture Walks either alone or with other classmates. If they are with other classmates, they have the ability to "talk" (through text) with one another about what they are seeing. If they are alone, they may share what they have visited with each other through oral discussion, through threaded discussion boards, or through another type of media. They also may choose to share what they have learned and have seen to others outside of the classroom, through "Cultural Exchanges" (luncheons which are given on campus for other students, staff, and faculty) or through visits to other students in other classes or at other schools.

Culture Walks are also valuable in meeting Standard 5.2. Students, when thinking about going abroad, can stroll through different locations to see what they are interested in. Then, with this knowledge, the student may enrich what they have learned through going abroad, going to see a film in the target language, or listening to music in the target language, to name a few of the possibilities. This will provide them an opportunity to develop both language skills and an understanding of the culture. Examples of these types of activities can be found in the attached Appendix A.

\section{STUDENT PARTICIPATION IN CULTURE WALKS}

World of Diversity provides an opportunity for students to build both language skills and cultural competence. In order for students to want to participate, it is necessary to motivate them and show them that they are completing a task for a reason and hopefully inspire them to want to continue learning through exploring.

It is well-known that, in order for a student to learn a language and to become culturally competent, the student must be motivated and have a purpose for wanting to learn a language and about different cultures. Gardner and Lambert (1959) distinguished between two types of motivation: integrative and instrumental. Integrative motivation deals with a learner's positive attitude toward the target language group and its culture, including meeting and interacting with other members of the community. On the other hand, instrumental motivation deals with learning a language for a purpose, such as getting a job, passing an exam, etc. Culture walks provide positive input for both types of motivation as students can both use Culture Walks as well as create their own Culture Walks.

\section{Using Culture Walks}

Whether or not students are motivated, we are challenged with coming up with activities which will provide the student the possibility to use the language in as authentic a context as possible. Instead of the teacher-centered classroom, World of Diversity and Culture Walks provide the perfect opportunity for students to gain both language proficiency and cultural competence. These activities can range from very straightforward to more advanced language skills.

The most basic use of Culture Walks by students would be to stroll through the different locations, reading and digesting the information. An extension to this activity might be a "report back", either orally or in the form a composition which might be informational or a compare/contrast with American culture. 
A second example which would be a bit more difficult would be to interact with the objects in the different rooms. For example, "eat tapas" in a restaurant or "make tapas" in a restaurant if there are none. Another would be to ask advice of El Buho. Then, as an extension to these activities, students might need to do some research into the type of "tapa" he/she ate and report back or write an informational essay. Or, a student might need to find equivalents to the idiomatic expressions that El Buho gave as advice and either discuss the different representations found in the Spanish idiomatic expression compared to a similar expression in English.

Another example which would be to visit one of the Cultural Centers or one of the Libraries and "check out" a "Video" or an "Audio" tape. With this activity, the visitor may sit and watch a short cultural video clip (for example, "Christmas in Spain", "The Running of the Bulls in Spain", "Day of the Dead in Mexico", etc.) or listen to music clips from famous musicians from around the world. Then an extension to that task might be to write a "review" of the video clip in the target language on a "note board" in the Cultural Center to either recommend or not the video clip or the audio clip.

Finally, a more advanced activity would be visiting a "bar" in one of the locations in which there is a "tertulia" (discussion) taking place. An example of a representative activity done is a discussion of what "to give someone the evil eye" means, signifies, represents. In one of these discussions, students had been reading a novel in which this particular theme came up. Using the Bar Mejillones (a well known space for "Tertulia") in Madrid, Spain, as a meeting place for students and anyone else who might have been connected at the time, the instructor broached the subject of "the evil eye", which provoked a very lively discussion between students with many different beliefs. An analysis of the discussion logs showed equality within discussions; that is, students who would not generally speak in front of the class or participate very actively in class discussion ventured to participate in the on-line, collaborative discussions. It has been stated that this equality is due to (1) a reduction in social context clues which are related to race, handicap, gender, accent and status (Sproull and Kiesler 1991); (2) a reduction of nonverbal cues (smiling, frowning, hesitating, etc.) (Finholt, Kiesler \& Sproull 1986); and (3) the ability of participants to contribute at a pace which is suitable to him/her (Sproull and Kiesler 1991). Student reactions to these collaborative activities was quite positive. Comments such as "I wasn't nervous at all about making mistakes," "I didn't know I knew so much Spanish!", and "We should do this more often" are all representative responses. After this discussion, students were able to relate to what a real "tertulia" would be like if they were sitting in the bar in Madrid in real life.

\section{Creating Culture Walks}

In addition to Culture Walks which have been created for students (as well as the general public), much of the learning that goes on is incidental. As Fanderclai (1995:8) states, “...Quite possibly they learn more from projects and activities they invent for themselves than from any I assign; certainly they learn things I could not teach them in our four-walled classroom." Students learning a second language have experimented and created their own objects in the target language many times and come to share the robot, or the "talking baseball", or whatever they want without having been assigned to do it. This play has led to increased language (both grammar and vocabulary) and culture ability. Included in this building have been Culture Walks in the target language, but which are related to their own culture. It is here where students have been able to experiment with the language while using their own culture (in this case, American culture, and more specifically, rural Pennsylvania culture) as a point of comparison.

Another possibility for students to help in the creation of Culture Walks would be for them to volunteer to be part of a project which is being conducted by either a native speaker of the target language or a teacher who has experience and knowledge of that particular part of the world. This may be done through the VASE system in World of Diversity.

The Virtual Project Board (VASE) is located within World of Diversity and provides a platform in which those with permissions to make create (i.e., anyone who has become a "builder" or who is a "programmer") may design a project for anyone who is part of World to work on. The designer has the ability to accept or reject a request to work on a project. Figure 13 below shows the basic layout of a project. The designer provides a Project Title, and can designate a course (or courses) or leave the project open for anyone to participate. The participants then "register" to work on the project and state what it is that they want to do. As they are working, the can submit what they are 
doing to be reviewed and/or to receive comments and guidance from the Designer. The Designer may delete participants and/or content he/she feels is not appropriate for the project.

Figure 13: Virtual Project Board

\begin{tabular}{|c|c|c|c|c|}
\hline Project Title & Course & Designer & Participants & Designer \\
\hline Creando "Caminos Culturales" & & Debbie & [Edit] & $\begin{array}{l}\text { [Edit] } \\
\text { [Manage] }\end{array}$ \\
\hline \multicolumn{5}{|c|}{$\begin{array}{l}\text { Brief Description: Con este proyecto, vas a crear "Caminos Culturales" o sea, vas a crear una excursio'n por una ciudad, un museo, etc. El u'nico } \\
\text { requisito es que toda la informacio'n debe ser en tus propias palabras, debe ser creativa, y debe ser aute'ntica. Si usas ima'genes, deben ser tuyas } \\
\text { debes tener el derecho de usarlas sin permiso. Si tienes dudas, de'jame saber. }\end{array}$} \\
\hline Creating Culture Walks & & Deborah Gill & [Edit] & [Manage] \\
\hline \multicolumn{5}{|c|}{$\begin{array}{l}\text { Brief Description: The purpose of this project is to create walking tours in different countries and including important information. These should be } \\
\text { creative, using ONLY AUTHENTIC MATERIALS WHICH BELONG TO YOU OR THAT YOU HAVE PERMISSION TO USE. }\end{array}$} \\
\hline
\end{tabular}

Figure 13 is a description of the "Culture Walks" which are being created in Spanish, with a parallel project in English. These tours are comprised of written narrations, video and audio clips, and/or authentic photos taken by the author of this paper or photos which have been donated for use free of copyright issues. The "Brief Description" within each Project explains the purpose as well as any special requirements (i.e., in this case, the use of authentic materials).

\section{BECOMING INVOLVED IN THE CULTURE WALK PROJECT}

The Culture Walk Project is an ongoing project which is always looking for collaborators. The number of Culture Walks is infinite. Culture Walks may be created in any language, with the focus on any location on any continent in the world.

If you are interested in becoming part of the Culture Walk Project, please reading the information which is found on the World of Diversity home page (http://diversity.ds.psu.edu/World_of_Diversity/index.html). Here you will be able to read our Mission Statement and learn how to become part of the World of Diversity community. By sending a message to Dr. Deborah Gill, psu_diversity@yahoo.com, with the subject line "Culture Walk Project", you will be made part of the Community and, once you have completed the tasks in World of Diversity to allow you to become a builder (or a programmer if you prefer), you will be able to begin the creation of your Culture Walks and/or set up a VASE project for others to collaborate with you.

\section{CONCLUSIONS}

In this paper we have attempted to show how Hispanic Culture can be taught (and enhanced) through Culture Walks. Culture Walks provide an opportunity for visitors to be able to gain cultural competence through strolling through regions, read static objects found in different locations, interacting with objects, and participating in synchronous "tertulias".

Culture Walks also provide an opportunity for language learners to meet local, state, or national standards of language knowledge and cultural competence. Through reading, writing, listening (to authentic audio and video found in the Cultural Centers or in the Libraries), and speaking (through text), students will gain a better grasp of different cultures and an ability to compare other cultures to their own. This is the ultimate goal in showing that a person has achieved cultural competence and has gained a more international and global perspective. 


\section{REFERENCES}

1. Duranti, A. 1997. Linguistic Anthropology. Cambridge: University Press.

2. Fanderclai, Tari Lin. 1995. MUDs in Education: New Environments, New Pedagogies. Computer Mediated Communication Magazine 2/1:8.

3. Finholt, T., Kiesler, S. \& Sproull, L. 1986. An electronic classroom. Working paper. Carnegie Mellon University:Pittsburgh, PA.

4. Gardner, R.C. and Lambert, W.E. 1959. Motivational variables in second language acquisition. Canadian Journal of Psychology. 13:266-272.

5. Kramsch, C. 1993. Context and Culture in Language Teaching. Oxford: Oxford University Press.

6. National Standards for Foreign Language Education. 2004. <<http://www.actfl.org/public/articles/ details.cfm?id=33>>

7. Sproull, L. \& Kiesler, S. 1991. Connections: News ways of working in the networked organization. Cambridge:MIT Press.

\section{APPENDIX A: CULTURAL COMPETENCE ACTIVITIES USING CULTURE WALKS}

Below is a brief list of Cultural Competence Activities Using Culture Walks which are developed, or may be developed, in World. The list is not all inclusive and any other activities that one would like to create would be welcome!

1. Culture Walks. These are the foundation for Cultural Competence Activities. They are virtual walking tours which may have oral narration as well as video clips, photos, and text. These can be used for very basic Spanish courses (they are not narrated in advanced Spanish) to more advanced Spanish language and culture courses. The information learned here can be transferred into the face-to-face classroom meetings for discussion as a class, a writing activity, a group collaboration, etc.

2. Like to cook? Recipes provide a wide breadth of cultural knowledge to the classroom. There are a number of "recipe books" throughout World of Diversity, found in the different bookstores and libraries at different locations in the Culture Walks. These "recipe books" provide foods from all over the world. With these virtual recipe books, students can compare foods from different countries as well as try to prepare different foods. These recipe books can also be seen as "language acquisition activities", with new vocabulary as well as the ability to practice grammatical forms which they have learned in their courses.

3. Mazes. Currently there are a series of mazes created in Spanish. Although the mazes themselves are not within the Culture Walks themselves, much of the information needed to be able to complete these mazes may be found within the Culture Walks. Therefore, the "maze" would be an activity that is an extension to the Culture Walk itself. These mazes go from very basic Spanish (i.e., "The capital of Mexico is ?") to advanced (i.e., "In what year was La Celestina written"). As students progress from the first level to the last, they are gaining cultural knowledge.

4. Let's Party!. Currently there are a number of "Dance Clubs" set up at different locations found in the Culture Walks. Each one is a little bit different. Those who are interested in a quieter atmosphere might enter into a Club which has tables, chairs, and a jukebox. Those who are daring might enter into one of the Clubs that has a bar, dance floor, objects which will dance with you, fortune tellers, etc. Generally there are a number of objects which students can interact with, for example, asking for and getting food, asking to have one's fortune read, etc. Each of these activities builds on the five skills necessary in language learning as well as a number of the National Standards for Foreign Language Education.

5. Cultural Center. A Cultural Center has been set up in order to provide a place where members of the community can meet to discuss and compare cultural differences. These Cultural Centers functions as the axis to which each of the separate culture walks connect and begin. This is also the spot where members of the community may view presentations on different holidays, folklore, etc. from around the world. Once again, this task meets all areas of the national standards. 